ject of the sensation of motion, has very clearly proved that this is not the case. Everything we know as to this sense leads us to look for its organ in the head. And there is an organ which, to some extent, at all events, seems to be what we are in search of. The macula acustica in the utricle is a spot well furnished with nerves, and we have $\mathrm{n}$ )t found out any special function for it. There is a similar macula in the saccule, that other membranous bag contained in the vestibule. Mach has suggested that the macula of the utricle may be the organ by means of which we perceive acceleration of translatory motion. Let as look at it, and see how far it is fitted to act as a level. Its length is stated by Prof. Schwalbe to be about $\frac{1}{3}$ of an inch, and its breadth a little less. According to the same observer, it covers a part of the floor, the anterior wall, and a part of the external wall of that part of the utricle called the "recess." Its nerves end, as has already been stated, in hair-cells, and these are covered by a gelatinous substance filled with a fine powder of crystals of carbonate of lime. What is interesting to us in this description is that it looks in three directions, and that the whole of it is covered with a powder of considerably greater density than the fluid (the endolymph) with which the utricle is filled.

Let us try to imagine a model of this structure. Let us take a box of glass, so that we may see what goes on in the inside of it. Let us put on a part of the bottom of the box, on the end of it, and on a part of the side of it, a layer of thin jelly mixed with fine sand. Fill up the box with water, and put on a lid. We shall find that we have an apparatus that does to some extent answer the purpose of a level. When we change its inclination, the jelly but for the sand would indeed have very little tendency to change its position, but the sand, being specifically heavie than the water will, and will either move through the jelly if that is thin enough, or pull the jelly with it. In any case, a change of position of the box will involve a change in the relative position of its contents. In the actual case of the macula acustica such a change in the relative position of the sand and the haircells must give rise to an irritation of the terminations of the nerves, and send a message to the brain. We cannot as yet work out all this in detail, as we can the way in which the canals give us information as to the acceleration of rotational motion, but we know enough to turn our attention to the subject; and we may hope that, by more accurate study of the sensation phenomena, and by comparison of them with the anatomical facts, this important and interesting physiological question may be satisfactorily answered.

\section{ON THE GEOLOGICAL HISTORY OF THE} PREHISTORIC FLORA OF SWEDEN.

FIFTY years have passed since the Danish Professor, Japetus Steenstrup, presented to the world his masterly researche on the history of Denmark's peat-bogs. These researches clearly demonstrated that the forests of Denmark had suffered remark able variations. The oldest forests had cunsisted chiefly of aspen (Populus tremula), next, for a long period, of Scotch fir (Pinus sylvestris), then of oak, and, finaliy, of alder (Alnus olutinosa). Remains of the beech-now Denmark's chief species of tree-are, however, entirely absent from the peat-bog. Consequently, it must have been the last to immigrate. It was a natural surmise--and one even advanced by Steenstrup -that the changes referred to were connected with a gradual softening of the climate, a view defended, too, by Prof. Forchhammer.

But Steenstrup's researches were in advance of their time; glacial geology was only in its infancy, and voices were therefore raised both in Denmark and Sweden claiming to interpret these changes in the forest vegetation as one of Nature's great systems of evolution, whereby one variety, so to speak, prepared the soil for the next comer, without any reference to climate. However, this view has now but an historical interest. For, since our knowledge of the geology of the Glacial age has become more and more enlarged, and since remains have been found in Scania of a true Arctic flora embelded in the fresh-water clay deposits of that province, a return to Steenstrup's theory that the changes of climate and forest vegetation were related was but natural. Indeed, the same Arctic flora was shortly discovered underneath the aspen layer in the Danish peat-bogs, so that the aspen fora cannot be regarded as the first a'ter the Glacial age. By degrees, as the ice melted, the denuded soil was invaded by the Arctic flora from the south. First, when the climale became still milder, and a forest vegeta tion could flourish, the aspen and the birch immigrated, and in turn the pine, oak, and alder. Each one formed in its day the forest of Denmark, and they were naturally accompanied each by its own peculiar undergrowth of shrubs and plants. Enormous ages elapsed between these events. The remains of the peat-bogs show that generations upon generations of grand firs flourished before the oak immigrated and before the pine flora was at last ousted. And in its turn the oak reigned supreme during countless ages, until that, too, was extinguished by the alder and the beech. During the fir period, the men of the Stone Age spread themselves over the land; when the fir was supplanted by the oak, the Bronze Age began. If we bear in mind how exceedingly slow the extension of the oak and the beech is, we can form some idea of the imniense time that must have elapsed since the Ice age.

Therefore the flora of Denmark consists entirely of the offspring of immigrated plants. Many of the species which appeared in the country did not remain; to them Denmark was only a station on the road towards higher latitudes. This was, for instance, the case with the greater portion of the Arctic flora, as well as with the fir. From the beginning of the bistorical period the beech has flourished throughout the whole country.

In Sweden, in districts rich in calcareous matter, tuff strata are deposited from springs which, by their contents of carbonic acid, contain carbonate of lime. When calcareous water is exposed to the air, the carbonic acid gas evaporates, and the carbonate of lime is precipitated in the form of a white deposit, which soon hardens to stone. Such a deposit is therefore particularly natural around the mouth of a spring or in some pool into which the calcareous water is discharged. Consequently the leaves or other remains of plants growing around are covered, soon after falling into the water, with a thin coating of chalk, and although they are by degrees destroyed, this imprint in the chalk remains - often so distinctly that the finest fibres of a leaf may be traced.

A necessity for the formation of calcareous tuff is therefore the presence of calcareous rocks, whence the water may draw the lime. And, indeed, with us all calcareous tuff deposits, as far as we know, are confined to where the chalk formations are richest, as, for instance, Scania, Western and Eastern Gothia, Jemtland, Angermanland, and Åsele Lappmark.

The greatest in extent and richest in leaf imprints are the old well-known tuff strata at Benestad, in Scania, north of the town of Ystad. 'They were formerly largely' worked for building purposes, as, for instance, for several churches. The tuff is referred to by early writers as rich in leaf imprints, but in their writings a serious error crept in, viz. that even leaves of the beech were imprinted. This is wholly without foundation.

In consequence of the quantity of stone removed, it is now impossible to fix precisely the nature of the stratification, and what we know on this point is due to the particulars supplied by Baron Claes Kurck, who carefully examined the strata. His researches fully confirm the views of the writer, expressed as far back as 1872 , viz. that the oldest strata were deposite 1 whilst the aspen was the predominating tree in the districts, and before the fir had immigrated. Kurck has also found here traces of birch, grey sallow (Salix cinerea), and possibly the common sallow (Salix caprea). Above this stratum we come to the fir, deposited when that predominated. The imprints of the fir, in the shape of needles, branches, bark, and cones, show that this tree grew clo:e by the springs. Most of the tuff dates from the fir period, but during the same age other species of trees gradually immigrated, of which indications are found in the lower parts of the fir deposit. From these the National Museum possess a rich collection, chiefly made by Nordenskiöld in 1873. It contains several rare species of plants, and the imprints of leaves are so. remarkably clear that the collection is one of the greatest ornaments of the palæontological section.

Of the trees which fourished contemporaneously with the fir, we learn from Kurck that the birch, mountain ash (Sorbus aucuporia), Salix caprea, and Salix aurita, were the oldest, and the hazel but little younger. To somewhat later strata he refers dog-wood (Cornus sanouinea) and berry alder (K'hannus fran. grula), and he believes that the remains found of Dutch rush (Equiseinn hyemale), and the guel ter rose (Viburnum opulus) also date from the same period. If this be the case, it is probable that some leaves in the Nordenskiöld collection of hawthorn (perhaps Cratcegus monogyna) also belong to this stratum. 
Naturally, the species named also appear in this collection. The later strata from the fir period are, according to Kurck, distinguished by a quantity of leaves of the mountain elm (Ulmzbs montana). Leaves of hazel, birch, aspen, \&c., are also found; whilst, for the first time, leaves of the lime (Tilia parvifolia) are met with, but very rarely. In this stratum Kurck has also found the common bracken (Pteris aquilina) and meadowsweet (Spirad ulmaria). Some leaves of the alder he believes to be still younger.

Besides the species named-which are all found with remains of the fir-are some others. Already in Nordenskiöld's collection notice was attracted to portions of a stratum in which the fir was absent, and which in a measure differs in appearance somewhat from the rest of the tuff. These portions contain leaves of the mountain ash, the common oak (Quercus pedunculata), viz. hazel, lime, salix, and birch. This stratum has been re-discovered by Kurck, and is, as might be expected, younger than those named. It may be added that, according to earlier writers, leaves of the maple (Acer platanoides) have also been found at Benestad, but latterly none have been discovered.

It would seem, then, that there is at Benestad a counterpart to the Danish aspen, fir, and oak periods ; but we cannot quite say that as regards the second period. There is, for instance, nothing to prevent the fir having vegetated, through some accidental causes, at Benestad, even during a part of the oak period. 'This is the more likely as we find the tree at the present day in Northern Scania. If, therefore, on the one hand, it is certain that the elder pine strata at Benestad belong to the true fir period--the time before the immigration of the oak-it cannot, on the other, be denied that the younger section of the fir strata may have been deposited already when the oak immigrated thither. That some of the fir-bearing strata must have been deposited relatively late seems eviclent from the presence of such plants as dogwood, hawthorn, elm, \&c. However, the problem will no doubt be final'y solved when once the peat-bogs of the province have been palæontologically examined.

Of the beeches and hornbeams (Carpinus betulus), now common in the district, there are no traces in the strata, and although the springs still yield plenty of water, there appears to be no deposit of calcareous tuff whatever. Thus, all we are really able to say respecting the palocontological remains in the fir period at Benestad is that these plants immigrated before the beech, and, most probably, even before the oak, and that all of them came from the south-west.

Respecting the flora which flourished in Scania previous to the aspen and fir periods, we know its characteristics through the vegetable remains in the fresh-water clays of the provirce. They display a rich Arctic flora, comprising Dryas octopetala, Salix polaris, herbacea, reticulata, Betula nana, Oxyria digyna, \&c. An animal fossil must also be mentioned, only recently found among them, viz. Apus glacialis, now common in Spitzbergen lakes, but which in Scandinavia is not found south of the lakes in the Dovre Mountains.

In proportion as the inland ice melted, the Arctic flora, so rich in varieties, advanced, but as the climate became milder this flora was replaced by the forest vegetation immigrating from the south, and, at all events at Benestad, the trees followed each other in the same succession as in Denmark, viz. aspen, fir, oak, whilst the beech immigrated considerably later. It is most probable that the forest vegetation followed in the same order in the whole of Southern Sweden, but we do not know this with certainty. For we still know too little respecting the remains of plants in the peat-bogs of Southern Sweden. That we are far behind in this respect is chielly due to the circumstance that in Denmark the peat-bogs are turned largely to profitable account.

Of the calcareous tuff strata in the province of West Gothia we know unfortunately very little. They are, however, small in extent, and contain only remains of trees still found in the neighbourhood, viz. hazel, salix, and aspen. Near the Eskedal railway station there is certainly a very large deposit, but not formed of continuous tuff, but of loose calcareous débris, which does not retain imprints.

In East Gothia we have two calcareous formations, one near Vreta cloister, which appears to be of a rather recent date, as it contains salix, hazel, oak, and lime. The other, north of Vadstena, is, however, much older, and therefore of great interest. This contains, among other remains of a pure Alpine plant, Dryas octopetala (L.), which we already know from the Scania fossil glacial flora, besides dwarf birch (Betula nana), and perhaps also Betula intermedia. There are also leaves of several varieties of willow, birch (Betula odlorata), crowberry (Empetrum), Vaccinium ulivinosum, and fir needles. The discorery of Dryas in this locality is of the highest interest and importance, as it leads us to hope that we may discover in other parts of Sweden between Scania and Jemtland remains of an Arctic flora, which, judging from the discovery referred to, must, at all events partly, have advanced from the south through the whole country. Formerly we did not possess a single palæontological proof from this part of Sweden in support of this assumption. The discovery is also of great interest in another respect, inasmuch as it shows that Lake Vettern must have become separated from the Baltic, with which it was once connected, at a time when the climate was Arctic-an assumption in full accord with Prof. S. Lovén's discoveries respecting the Arctic Sea fauna that to the present day is found at great depths in this lake.

The Jemtland strata liave of late been examined by Herr A. F. Carlson. This province is rather rich in calcareous tuff deposits, some twenty localities having already been disc svered. Here, too, the first forests appear to have consisted of aspen, birch, chiefly betula odorata, and fir, of which latter remains have been found in several places. In four localities Dryas octotetala have been found, and in two Salix reticulata, both of the Arctic flora. As the former were found at Fillsta and Digernäs, in Sunne parish, and the other at Semla, in Mörsils parish, it would appear to be proved that the Alpine flora of Jemtland formerly had a far greater extension within the province than at present, and that at that period it reached as far as the basin of Lake Storsiö. Without doubt an examination of the fresh-water clays of the province would go to show that the Alpine flora formerly covered the whole of Jemtland. The tuff strata which contain such remains were deposited a little later, whilst the Alpine flora was in process of being displaced by the forest vegetation.

The remaining plants that have been found in Jemtland are Dutch rush (Equisetzm hyemale), salix, several varieties of willow, dwarf birch, Betula intermedia and alpestris, Alnus incana, crowberry, mountain ash, Sorbus aucuporia, Vaccinium uliginosum, and sea buck thorn (Hippophä rhamnoides).

From the province of Angermanland we know two tuff deposits, near each other, but the palæontological remains are few and badly preserved. Here have hitherto been found only some lichen, fir, birch, salix, and willow.

In Asele, Lappmark, between Långfors and Långsile, there are two deposits - as far as we know the northernmost in Sweden. Both are rich in leaf imprints, and thanks to Colonel N. Sjöberg, of Åsele, the National Museum has obtained specimens. The species are certainly not numerous, but they are well preserved, and consist of lichen, leaves of fir, birch, aspen, salix, səme willows, and Hippophaë rhannoides.

As I have already stated, leaves of this plant have also been found in a spot in. Jerntland situated more than I 500 feet above sea-level. Here the leaves are found in common with remains of Dryas, but whilst the latter now has to be sought high up in the mountains, the former is, on the contrary, only found by the coast. It is found along the shores of the Baltic, from Roslagen (near Stockholm) to Vesterbotten in the north, and the thorny shrub, with its whitish silvery leaves, and yellow or chrome-coloured sour berry-like fruit, here goes by the name of haf-thorn (i.e. sea thorn). In other parts of Central and Northern Europe where this shrub grows, it is also a coast plant, but it is found beside the glacial rivers of the Alps; and its former existence in the localities named in Norrland-right in the heart of the country, high above the sea, together with other Arctic plants-shows indisputably that here also it was originally an Arctic plant. But whilst Dryas, Salix reticulata, \&c., were forced northwards by the immigrating forest flora, this plant, on the contrary, found a place of refuge on the seashore, where it flourishes to the present day. It seems, indeed, hardly credible that two plants now so widely separated, geographically, as Dryas in the high mountains and Hippophae by the Baltic shore, once grew side by side in the heart of the country.

Having dealt with the proof: respecting the former extension of the Swedish flora furnished by the palaontological remains of the calcareous tuff strata, I purpose to touch upon an equally important point, viz. that the spruce immigrated comparatively late. In no single tuff deposit has trace been found of this tree, and this circumstance is too uniform throughout to be a matter of accident. Especially peculiar are the conditions in 
Temtland, where severai of the localities in which the palæontological discoveries were made are surrounded by spruce forests, and where the tree grows higher up on the mountains than the fir, which is the reverse of what is generally the case. In Jemtland, therefore, the spruce clearly immigrated after the fir, and first when the principal tuff formation had ceased. Whence did the spruce immigrate into Sweden? It cannot have been from the south or from Denmark, for remains of the tree are totally absent in that country's well.explored peatbogs, neither does it belong to Denmark's present wild flora. Neither can the spruce have come from the Jiritish Isles. Certain'y it appears from palæontological evidence that the spruce existed in England before the Ice age, but it appears to have been extinguished during that age, as it is absent from the post-glacial deposits as well as from the IBritish flora of the present day. Finally, the scarcity of the spruce in the western parts of South-Eastern Norway fully proves that it did not immigrate from the west. There cannot, therefore, be the slightest doubt that the spruce immigrated into Sweden from the east. This assumption corresponds entirely with the present extension of the tree east of the Baltic. But this immigration cannot have taken place via Northern Sweden around the Gulf of Bothnia, as this part can be supposed to have had only at a later period a climate mild enough for its existence. It is more probable that the immigration tork place, vid the Island of Gothland on the south east coast, or witi the Aland Islands, off Central Sweden, and that the spruce afterwards spread north, west, and southwards.

It may be mentioned, by the way, that the sprice existed in the neighbourliood of Enköping at the time when Lake Mälaren was a bay of the Baltic, and the sea covered the spot where the town is now situated. Of great importance with regard to this point is the discovery recently made $b \%$ Dr. $\mathrm{H}$. Munthe, that the spruce was found in Gothland at a time so far remote that the division of land and sea then was wholly different from that which at present exists. This seems to speak for the immigration cf the sprace by this road. Further, Dr. R. Hult, of Helsingfors, last summer discovered in West Nyland, in Finland, sub-fossil remains of spruce in a stratum which he estimates to be older than the remains of spruce found in Scandinavia, and he therefore considers that the spruce immigrated fro a Finland.

Considering the present and past extension of the spruce in Europe, one might be inclined to assume that the true home of this tree was Scandinavia, whence it was driven in the Glacial age, but this, it is now being demonstrated, was not the case.

Now, the spruce, in spite of its relatively late immigation, has in Sweden spread greatly, forming huge forests; and we might be disposed to conclucle that in its turn it would extinguish other species. Experience from our forests goes to prove that this is really the case. Thus, from Southern Sweden we know from the researches of Dr. R. Hult in Blekinge that the spruce (except in dry localities) generally extinguishes the fir. And reports by Herr C. G. IIolmerz and Herr Th. Ortenblad show that this is also the case in Norrbotten, where "the spruce in all more favoured localities wedges itself in between firs and birches, and finally exterminates its predecessors in occupation." Even the oak is ousted by the spruce. Prof. Elias Fries states that " the spread of our noblest foliage tree is being arrested in recent times. In a primæval spruce forest, where there is no more oak in the locality, I have found below an immence layer of moss oak trunks of such dimensions that I doubt whether there are their equal in all Sweden." In Blekinge also similar facts have been brought to light, and recently Prof. F. R. Kjellman expressed the opinion that "the oak flora formerly had a greater extension in our country, but has been thrust aside by the spruce."

Although the spruce is victorious over some species, it is unable to conquer the beech. Therefore there is little chance that the spruce will take possession of our southern counties.

In conclusion, as the result of the known palæontological facts respecting the immigration of our flora, we are able to express the opinion that the greatest part of the Arctic flora, as the inland ice melted, immigrated from the south; and that, of the various forest trees, the birch, aspen, and fir came by the same road, forming the country's oldest forests. From the south, too, we must assume that salix, mountain ash, mountain elm, hazel, lime, with accompanying shrubs, certain willows, guelder rose, Rhammus frangula, Cornus sanguinea, and the hawthorn came, and from the same quarter, at a later period, the common ash, oak, and ivy. Furthermore, later still, the beech and the hornbeam, with accompanying shrubs, came from this quarter. The spruce and the beech both immigrated late, but the former from the east. These two forest trees are at present, in different localities, the two most favoured, the beech in the south, and the spruce in all other parts as far as the northern limit of coniferous trees. But the contest between the different species of trees is no longer undisturbed. For since man settled in the land a new factor has arisen, and this factor participates both directly and indirectly in the contest. Originally slight, his influence has grown greater and greater, and the time may come when he will be the arbiter as to the trees that are to form the forests of the future.

Geological Survey of Sweden.

A. G. NATilorst.

\section{AGRICULTURAL EXPERIMENTAL STATIONS IN THE UNITED STATES.}

THE following interesting information in reference to the establishment of agricultural experimental stations in the United States is given in a memorandum recently issued by the Agricultural Department of the Privy Council, and laid before Parlia ment. An "Office of Experiment Stations" has been instituted as a special branch of the United States Department of Agriculture. For the expense in connection therewith a sum of f2000 was voted by Congress in 1888 , to enable the Commissioner of Agriculture to carry out Section 3 of the Act of Congress of March 1887 , by which experimental stations were cstablished. This said section provides that, "in order to secnre, as far as practicable, uniformity of methods and results in the work of the said stations, it shall be the duty of the United States Commissioner of Agriculture to furnish forms, as far as practicable, for the tabulation of results of investigation or experiments; to indicate, from time to time, such lines of inquiry as to him shall sem most important; and in general to furnish such advice and assistance as will best promote the purposes of this $\Lambda$ ct. It shall be the duty of each such station annually, on or before February I, to make to the Governor of the State or Territory in which it is located, a full and detailed report of its operation, including a statement of receipts and expenditure to the said Commissioner of Agriculture, and to the Secretary of the Treasury of the United States." In I 888 an Act was passed by Congress maling an appropriation for the Department of Agriculture for the fiscal year ending June 30, 1889 , and for other purposes, appropriating frI $_{10,000}$, including the f2000 specially reserved for the Commission of Agriculture, for the purpose of endowing and assisting agricultural and experimental stations throughout the country. Besides this sum, the several States have contributed $£ 25$, o0o, making

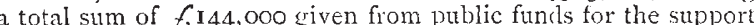
of these stations. There are now forty-six of these stations in the United States, so that, taking an average, each station will receive over $f 3000$ this year. It is said, how ever, that several of these stations have sub-stations under them, and that there are 370 trained men connected with the stations in the prosecution of scientific and practical agricultural experiments. The first agricultural experiment station in America was established in 1875 in Connecticut, and the next in California in the year following. In I879 the well-known Cornell University Station was founded, which has done so much good work, and the equally valuable Wisconsin Station in 1883 . No less than twenty-six stations were founded last year, in consequence of the inducements set forth by the Act of 1887 . In a recent Report as to the organization of these experimental stations, a list of the staff of each is given, from which list a few examples may be taken to show the extent of work that is performed, or may be performed. At the Connecticut Agricultural Station there is a director who is a Master of Arts, a vicedirector who is a Doctor of Philosophy, and a chemist. There are three other chemists who are Doctors or Bacheiors of Philosophy, a mycologist, and a practical farmer in charge of grounds and buildings. The staff of the Dakota Station is still more extensive, consisting of a director, a superintendent of the farm, a superintendent of forestry and horticultural experiments, an entomologist, an analytical chemist, a veterinarian, an accountant and stenographer, and a librarian. Upon the staff of the Iowa Station there are two chemists, one for ordinary and one for special work, a botanist for ordinary and special work, an entomologist, a veterinarian, a horticulturist, and a practical farmer. The Comell University Station staff comprises à chemist, veterinarian, botanist, and arboriculturist, a horticulturist, an entomologist, a cryptogamic botanist, besides an assistant in entomology, chemistry, veterinary 